\title{
TREE FERN APICAL TEMPERATURES AT THE ROYAL BOTANIC GARDEN EDINBURGH
}

\author{
Alastair Wardlaw ${ }^{1}$, Louise Galloway ${ }^{2} \&$ Andrew Ensoll $^{3}$
}

Tree ferns are difficult to maintain out of doors in the British Isles except in western localities, where winter temperatures are moderated by the North Atlantic Drift, or in places where buildings provide a clement microclimate. The present study of tree-fern apical temperatures during winter was carried out on five trunked specimens of Dicksonia antarctica that had been grown satisfactorily out of doors for several years, while planted in the ground of a courtyard at the Royal Botanic Garden Edinburgh (RBGE). The plants were never wrapped or otherwise protected with thermal insulation during the winter months. An electric thermometer was inserted into the apical cleft of each plant in November 2003, and weekly readings of minimum and maximum temperature taken until April 2004. The ambient temperature of the air in the courtyard was similarly recorded and compared with the screen and grass temperatures at the RBGE weather station in the main botanic garden.

The lowest grass and screen temperatures were respectively $-11.2^{\circ} \mathrm{C}$ and $-7.1^{\circ} \mathrm{C}$, whereas the lowest courtyard and fern-apical temperatures were respectively $-3.2^{\circ} \mathrm{C}$ and $-0.8^{\circ} \mathrm{C}$. Thus in the coldest period of that winter there was over $10^{\circ} \mathrm{C}$ difference in temperature between ground level in the main garden and a tree fern apical cleft in the sheltered courtyard.

The tree ferns were not noticeably damaged by exposure of the apical cleft region to just below freezing point on a few occasions and the fronds stayed green. The five individual plants differed considerably in trunk height, diameter and volume. Regression analysis revealed that there was a significantly increasing thermal-insulating effect in the apical cleft associated with larger trunk diameters and volumes.

The RBGE weather station temperatures during the winter of 2003-4 were unexceptional when compared with records from the previous 19 years. Thus the data from 2003-4 may be taken as representing a typical recent winter for this Edinburgh location.

This study highlights the benefits of having detailed temperature measurements when assessing the winter-protective capabilities of a particular micro-environment for a semi-hardy species such as $D$. antarctica.

\section{INTRODUCTION}

The tree fern Dicksonia antarctica Labill. comes from the wet, shady gullies and highrainfall forests of eastern Australia and Tasmania (Jones, 1998). Such habitats are rarely imitated when trunks of this species are imported to the British Isles, although it is customary to reduce wind exposure by planting them in a sheltered valley, woodland clearing, walled garden or courtyard. These locations, however, may not protect sufficiently against winter frosts, to which $D$. antarctica is susceptible (The Royal Horticultural Society, 1989). The exact degree of frost sensitivity is not well delineated,

\footnotetext{
'Alastair Wardlaw is holder of the NCCPG National Collection of British Ferns and recent past-President of the British Pteridological Society. Address: 92 Drymen Road, Bearsden, Glasgow G61 2SY. Email: a.wardlaw@btinternet.com

${ }^{2}$ Louise Galloway is Indoor Department Supervisor at RBGE. Address: Royal Botanic Garden Edinburgh, 20A Inverleith Row, Edinburgh EH3 5LR. Email:l.galloway@rbge.org.uk

${ }^{3}$ Andrew Ensoll is a Senior Horticulturist at RBGE where he is responsible for the fern collection. Address: as above. Email:a.ensoll@rbge.org.uk
} 
and is likely to vary according to the size and age of the plant, the conditions of cultivation and the length of establishment in a particular site. Whatever the circumstances, it is unusual for $D$. antarctica to survive long-term out of doors in the British Isles without winter protection, except where the climate is moderated by the North Atlantic Drift, or there is sufficient protection from buildings.

Thus $D$. antarctica grows luxuriantly, and without winter protection, in many coastal gardens of western Britain (Rickard, 1987). The range extends from Cornwall northwards up the western seaboard, as far as Inverewe Garden in Northern Scotland. A particularly fine display of these tree ferns with tall trunks, has been maintained for more than half a century at one of the RBGE's three regional gardens Logan Botanic Garden, south of Stranraer. Even at Logan, however, D. antarctica has been killed during severe winters, short-trunked specimens apparently being the most vulnerable (Barry Unwin, pers. comm.). Away from such favoured locations, D. antarctica generally needs winter protection, by insulated wrapping or by transfer to a covered enclosure (Rickard, 2000).

Eastern Britain, by contrast, seems not to provide satisfactory conditions for tree ferns, although gardens in London (Wardlaw, 2004), and perhaps a few sheltered places elsewhere (Wareham \& Maitland, 2004), are exceptions. Whether this is due to more severe frosts in eastern districts or to other factors, such as a year-round drier climate; is unclear. It is striking therefore that in the Royal Botanic Garden Edinburgh (RBGE), which is inland from Scotland's east coast, a group of five trunked specimens of $D$. antarctica has been maintained out of doors in good condition for several years, and without winter wrapping. This well-chosen site, while open to the sky and therefore at risk from radiation frosts on clear nights, is within the courtyard of a building, with walls and windows on all four sides. These surroundings presumably create, through heat transfer and wind protection, a microclimate that is milder in winter than the main gardens and sufficiently clement for the tree ferns not only to survive the winter, but to thrive and to keep their fronds green.

The object of the present investigation was to determine the winter temperatures experienced by these tree ferns, in relation to their surroundings, and the extent of temperature benefit provided by the courtyard, as compared with the main botanic garden.

\section{MATERIALS AND METHODS}

Courtyard. The Inverleith Row building of RBGE contains an interior courtyard (Plate 1) of dimensions $6.5 \times 20.3 \mathrm{~m}$ that is open to the sky and bounded on all sides by twostory, harled-masonry walls with numerous windows, not double-glazed. Winter heattransfer from the building to the courtyard may therefore be considerable. The periphery of the courtyard has beds planted with tree ferns, a few other ferns and some shrubs (Mahonia napaulensis and Pistacia chinensis), while the central area is paved. Watering of the plants was largely dependent on natural rainfall, with only occasional artificial supplementation. At the time of the study there was no water tap or irrigation system installed in the courtyard. 


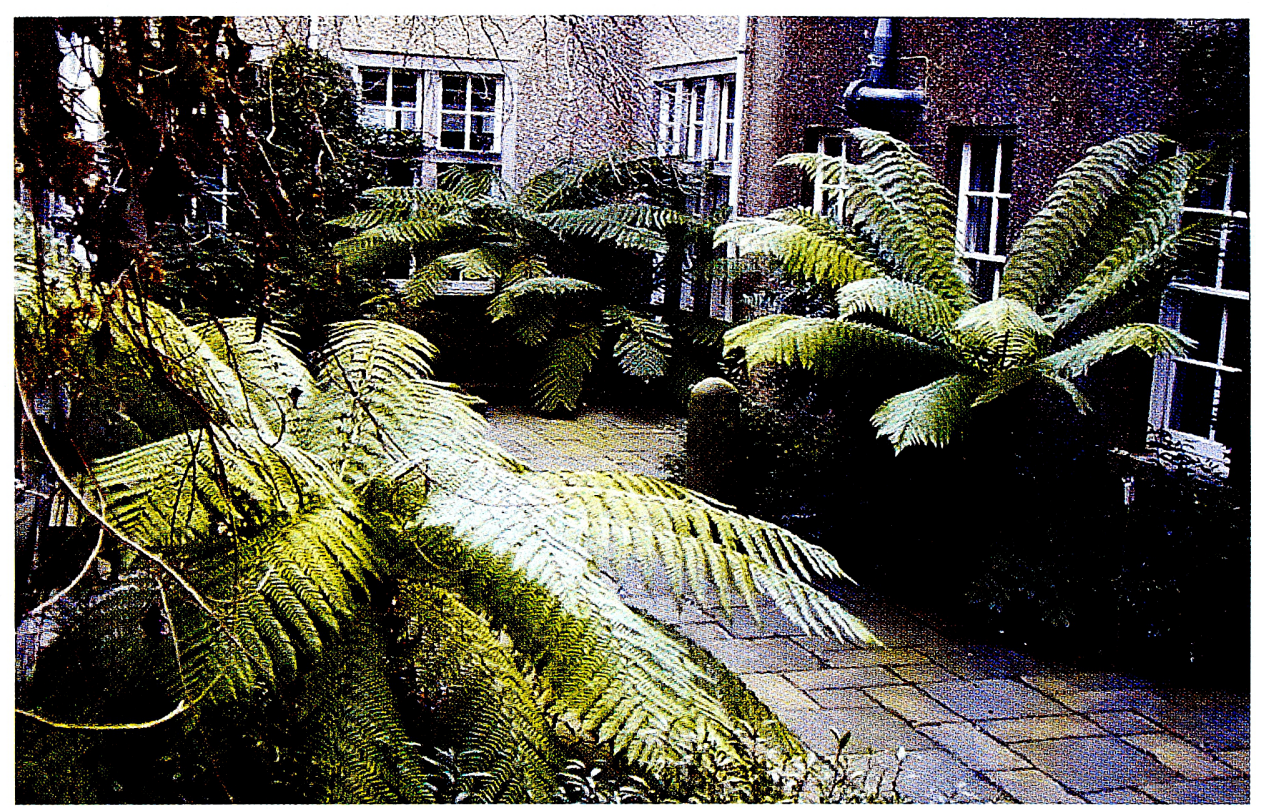

Plate 1. Internal courtyard at the RBGE building on Inverleith Row, showing four of the five Dicksonia antarctica which were the subjects of the investigation. Left to right, the plants are Nos. 5, 3, 4 and 2, whose particulars are given in Table 1. Tree fern No. 1, not shown, was located at the lower right, just out of the picture. Only No.5, adjacent to the south-facing wall received summer sun directly on its fronds. The case of an electric thermometer is just visible near the lower left corner of the right-hand window.

Tree ferns. Five trunked specimens of Dicksonia antarctica had been planted in the courtyard in 1998, having previously been in tubs under glass at RBGE. Their original provenance was New South Wales. In November 2003 their trunks ranged in height from 67 to $180 \mathrm{~cm}$ and their diameter near the top from 21 to $29 \mathrm{~cm}$. These physical particulars, including the number of fronds, are provided in Table 1 . The planting beds contained good quality garden loam and the tree ferns had not been given any fertilizer during the previous several years.

Temperature measurement. Each tree fern was fitted with an individual electric thermometer, Model No. BTH-112, from ATP Instrumentation Ltd, Tournament Way, Ivanhoe Industrial Estate, Ashby de la Zouch, Leicestershire LE65 2UU. The temperature sensors had a claimed resolution of $0.1^{\circ} \mathrm{C}$ and accuracy of $\pm 1^{\circ} \mathrm{C}$. Before use in the study, the thermometers were tested for equivalence by placing in a closed box whose temperature was raised slowly from 0 to $20^{\circ} \mathrm{C}$. All instruments gave the same readings to within $0.5^{\circ} \mathrm{C}$.

For use in the survey, each instrument had its sensor, at the end of a 2-metre lead, inserted as deeply as possible, but without damaging fern tissue, into the apical cleft at the top of the tree-fern trunk. To prevent dislodgement, the sensor-lead was tied to a stipe base for the duration of observations. The plastic case of each thermometer, containing another sensor, to measure air temperature, plus the electronics and display screen, was 
mounted on a cane approx $65 \mathrm{~cm}$ above ground level and as far as possible from the trunk. Rain protection of the thermometer case was provided by a plastic cover, perforated to allow free circulation of air while excluding water. Weekly readings of minimum and maximum temperatures, at each tree-fern apex and case, were taken over the 5.5 month period from 14 November 2003 until 30 April 2004. The thermometers were re-set after noting each week's readings.

These apical and courtyard temperatures were compared with the screen and grass temperatures in the official records from the RBGE weather station located in the main botanic garden. Official records of winter temperatures back to 1984-85 were also obtained in order to gauge whether the 2003/04 winter was typical, by comparison with the 19 previous winters.

Graphics and statistical analysis of temperatures and other data were done with Microsoft Excel and Minitab Statistics Software (Release 13).

\section{RESULTS}

Tree fern characteristics. The positions of four of the tree ferns in the courtyard are shown in Plate 1, which highlights their close proximity to walls and windows, and therefore to potential sources of warmth. The fifth plant (not shown) was in a corner beside a glass door and also close to a probable heat source.

Table 1 presents physical data on the five specimens of $D$. antarctica that were the subjects of the present study. The average number of fronds in November 2003 was 24 (range 17-31). The average trunk height was $116 \mathrm{~cm}$ (range 67-180) and the average diameter near to the top of the trunk was $25 \mathrm{~cm}$ (range 21-29). The approximate volume of each trunk was calculated from the height and diameter measurements and assuming a simple cylinder. Note that whereas the trunk volumes varied by a factor of 3.0 , the heights varied by a factor of 2.7 and the diameters by only 1.4 .

\begin{tabular}{|ccccc|}
\hline $\begin{array}{c}\text { D. antarctica } \\
\text { No }\end{array}$ & $\begin{array}{c}\text { No. of } \\
\text { Fronds }\end{array}$ & $\begin{array}{c}\text { Trunk dimensions } \\
\text { Height }(\mathbf{c m})\end{array}$ & $\begin{array}{c}\text { Diameter } \\
(\mathbf{c m})\end{array}$ & $\begin{array}{c}\text { Volume } \\
(\mathbf{l})\end{array}$ \\
\hline 1 & 21 & 105 & 28 & 64.6 \\
2 & 17 & 180 & 21 & 62.3 \\
3 & 28 & 136 & 29 & 89.8 \\
4 & 23 & 67 & 24 & 30.3 \\
5 & 31 & 92 & 25 & 45.2 \\
\hline Mean & 24 & 116 & 25 & 58.4 \\
\hline
\end{tabular}

Table 1. Number of fronds and trunk dimensions of the five Dicksonia antarctica in the RBGE courtyard.

Tree-fern and courtyard temperatures. The individual weekly-minimum apical temperatures of the five tree ferns between mid-November 2003 and the end of April 2004 are plotted in Figure 1. It shows that apart from a few divergences, for which we have no explanation, the five graphs were closely similar to each other and with much 
overlapping and criss-crossing. There were however, small but statistically significant differences between plants, in that tree fern No. 3, volumetrically the largest, had significantly $(\mathrm{P}<0.1 \%)$ higher temperatures than the others, which behaved as a group. These higher temperatures of No. 3 can be seen in Figure 1 where the dotted line tends to run slightly above the others for most of the time.

There were three occasions during the 5.5-month observation period when the measured apical temperature of one or more of the plants fell to $0^{\circ} \mathrm{C}$ or dipped slightly below. The lowest reading was $-0.8^{\circ} \mathrm{C}$ with tree fern No. 5 in early March. Other apical readings below zero were No. 2 with $-0.2{ }^{\circ} \mathrm{C}$ in early March, and No. 4 with $-0.3^{\circ} \mathrm{C}$ in late December.

By contrast with the tree-fern apical clefts, the weekly minimum temperatures recorded at the thermometer cases, i.e. the air of the courtyard, all showed readings below zero. The coldest temperatures were noted on 30 December when thermometer Nos. 1 to 5 recorded respectively $-2.3,-3.2-2.5,-2.5$ and -3.0 , an average of $-2.7^{\circ} \mathrm{C}$. For comparison, the corresponding apical temperatures were respectively $0.2,0.0,0.9,-0.3$ and $0: 3$, giving a mean apical temperatures of $+0.2^{\circ} \mathrm{C}$ and showing the insulating effect of the apical locations.

Small but statistically significant $(\mathrm{P}<0.1 \%)$ differences were found in minimum weekly readings of air temperature on the thermometer case-sensors in the five different positions in the courtyard. Thermometer No. 2 was on average about $0.5^{\circ} \mathrm{C}$ higher than the mean of the other four, which were within $0.2^{\circ} \mathrm{C}$ of each other. Figure 2 presents graphs (two lower lines) of the mean weekly minimum of the fern apex and courtyard air temperatures over the period of observation.

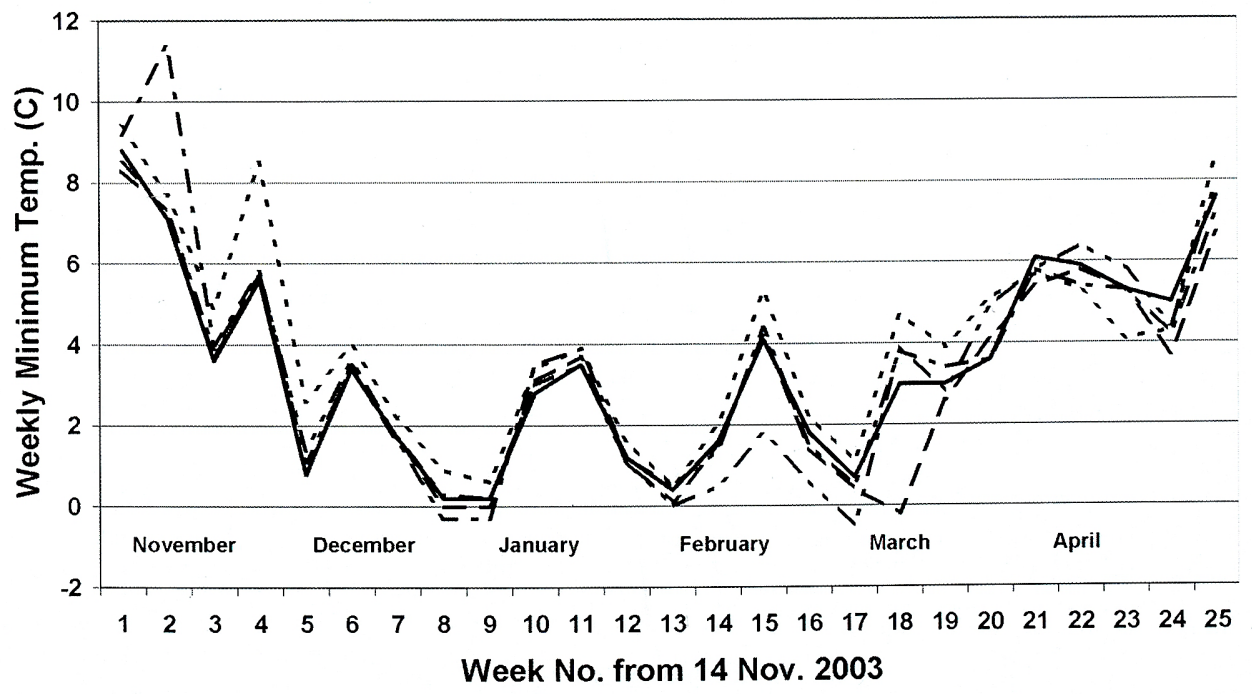

Figure 1 . Weekly minimum temperatures within the apical clefts of individual tree ferns, to show winter minima and between-plant variation. Tree Fern Nos. 1, 2, 3, 4 and 5 are represented respectively by lines that are solid, dash, dot, dash and dot, and dash and two dots. 
Figure 2 also plots the mean weekly maximum temperatures in the tree-fern apical clefts and in the corresponding thermometer cases. The insulating effect of the apical clefts is indicated by their maximum temperatures being lower than that of the air of the courtyard. Moreover, the insulating effect for heating the apical clefts, as reflected by the difference with the air temperature maxima, is greater than the insulating effect seen with the weekly minima. This is shown by the two upper lines in Figure 2 being on average further apart from each other than the two lower lines.

Insulation at the apical cleft. The possible relation between the insulating effect at the fern apical cleft and the size of the plant itself was investigated by regression analysis. For this purpose the difference between the weekly maximum for each apical cleft and the corresponding air temperature was taken as a measure of the insulating effect. This measure was then used as the independent variable for regression analysis against the trunk height, diameter and volume of the individual tree ferns. The most significant regressions $(\mathrm{P}<0.1 \%)$ were with trunk diameter and volume, of which the latter is displayed in Figure 3.

Comparison of courtyard and weather station temperatures. That Edinburgh experiences cold winters at ground level is well illustrated by the grass temperatures recorded at the RBGE official weather station. In the 2003/04 winter, every one of the 25 weeks between mid-November and the end of April had a weekly grass minimum below $0^{\circ} \mathrm{C}$. At the end of December and early January, weekly minima of -11.2 and $-10.6^{\circ} \mathrm{C}$ were recorded. There was a continuous period between 21 January and 10 March 2004 when every week had a minimum of $-6.0^{\circ} \mathrm{C}$ or lower. Even the week of 21 April recorded a grass temperature of $-5.0^{\circ} \mathrm{C}$. These grass readings are shown as the lowest line in Figure 4.

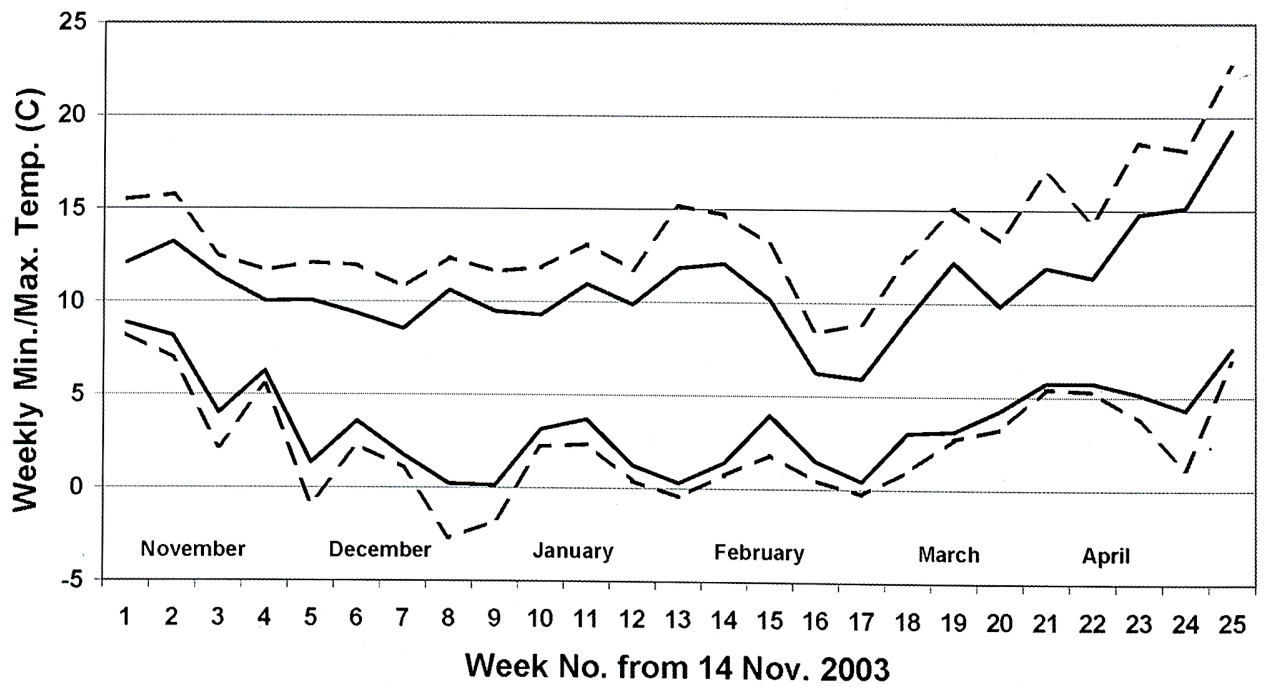

Figure 2. Means of the weekly minimum and maximum temperatures within the five tree-fern apical clefts (solid lines) and at the five thermometer cases (dashed lines). The two upper lines are the maxima and the two lower lines the minima. 
On average, the weather station weekly-minimum screen temperatures were $4.4^{\circ} \mathrm{C}$ higher than the grass temperatures of the corresponding weeks, and 17 of the 25 weeks of the study had a screen minimum below $0^{\circ} \mathrm{C}$ (dotted line in Figure 4). These data provide a baseline for demonstrating the moderating influence of the courtyard, whose weekly minimum air temperatures (dashed line in Figure 3) were on average $3.2^{\circ} \mathrm{C}$ higher than the screen temperatures. This moderating effect is also witnessed by only 5 of the weeks having a courtyard weekly minimum below $0^{\circ} \mathrm{C}$. Finally, the weekly-minimum tree fern apical temperatures were on average $1.25^{\circ} \mathrm{C}$ higher than the courtyard figures. There was no week in which the average of the apical minima was colder than $+0.22^{\circ} \mathrm{C}$, although some individual ferns had minima below $0^{\circ} \mathrm{C}$, as already noted. Overall, the average difference between the minima of grass and tree fern apical clefts was $8.9^{\circ} \mathrm{C}$, highlighting the cumulative moderating effects of the several thermally-protective influences.

Screen temperatures during previous winters. It was considered important to put the winter of 2003-4 into context by comparing it with previous winters. For this purpose the official screen temperatures were taken as indicators, and records of the 19 previous winters back to $1984-5$ were obtained. With each winter, the monthly minimum temperatures were abstracted for the months of November through to April, for comparison with the present study. In Figure 5, the study winter of 2003-4 is indicated by large open circles and the 19 previous winters as smaller solid circles. It is apparent from this presentation that the winter of 2003/04 had a temperature profile that was close-to-average for the last two decades. At least provisionally, therefore, the courtyard and tree fern temperatures for 2003/04 could be regarded as representing the likely results from an average of recent winters at RBGE.

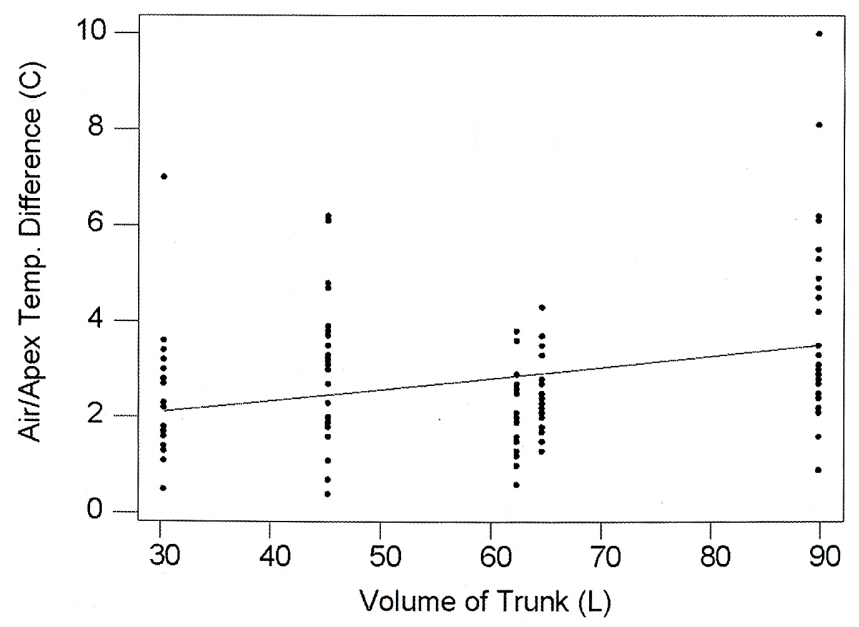

Figure 3. Linear regression of air/apex temperature difference (weekly maxima), on trunk volume, of the five tree ferns. 


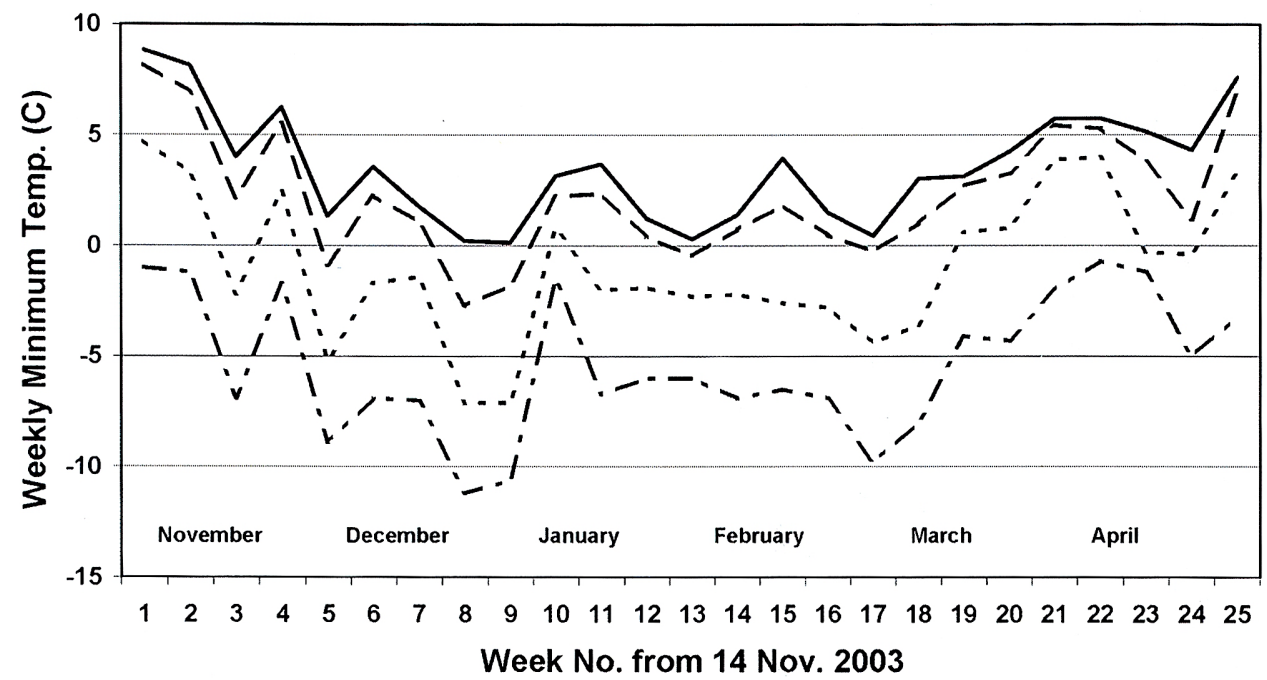

Figure 4. Comparison of weekly minimum temperatures in four locations: average of tree fern apical clefts (solid line), average of courtyard air (dashed line), weather station 'screen' (dotted line), and 'grass' (dash and dot line).

Dicksonia antarctica is commonly regarded as the hardiest of all tree ferns for use as a decorative garden plant, at least in the British Isles (Rickard, 2000). Writing from Australia, Jones (1987) categorised the species as 'very hardy to frosts and snow', but did not specify what this means in terms of temperature and duration of exposure. Hoshizaki and Moran (2001), primarily from an American perspective, described D. antarctica as 'semi-hardy to semi-tender' and quoted experience in California that one week at $-7^{\circ} \mathrm{C}$ withered the fronds but did not kill the plants; also that dormant trunks in shipments have been known to survive $-5^{\circ} \mathrm{C}$ for two months. The Royal Horticultural Society (1989) placed $D$. antarctica in the 'half-hardy' category, defined as 'can withstand temperatures down to $0^{\circ} \mathrm{C}$ ', which perhaps understates the hardiness slightly. Rickard (1987) in a survey of tree ferns growing out of doors in the British Isles concluded that nearly all gardens where these tree ferns thrive have fewer than 20 air frosts per year, while in gardens with 20-40 air frosts the plants do less well.

The observations reported in the present work do not challenge any of the above statements, although with the courtyard temperatures recorded only weekly, it is not possible to translate our observations into total number of air frosts on a daily basis. Nevertheless, the courtyard, with only 5 occasions in which a weekly minimum temperature below $0^{\circ} \mathrm{C}$ was recorded, was likely to have been within the 20 -per-year limit stated for tree ferns to thrive. By contrast, the main botanic garden outside the courtyard, with 16 weekly minima below freezing, would have been unlikely to meet this specification.

There have been very few published reports on the apical temperatures of tree ferns in freezing weather. Earnshaw et al. (1988) made pioneering studies on one plant each of Cyathea gleichenioides and Cyathea atrox var. atrox, growing at $3500 \mathrm{~m}$ in the alpine grasslands of Papua New Guinea. Despite being very close to the Equator, the ground 


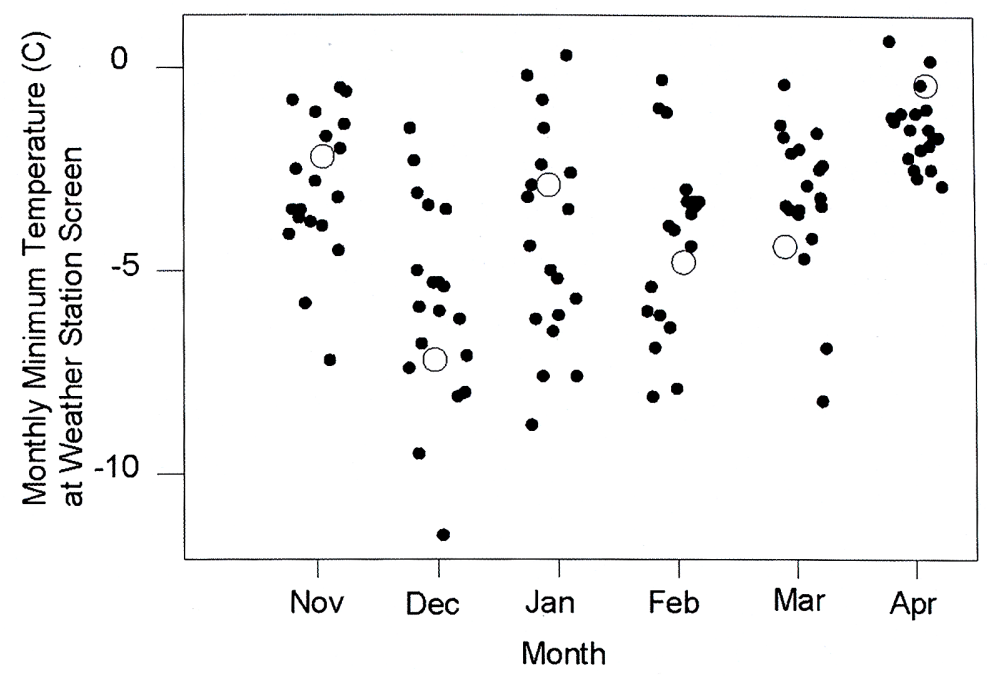

Figure 5. Monthly minimum screen temperatures at the RBGE weather station in the winter of 2003/04 (open circles) compared with those of the previous 19 winters (solid circles), back to 1984-85.

at dawn under cloudy, cool conditions registered $-3.0^{\circ} \mathrm{C}$, while the shoot apices were between 2.5 and $3.5^{\circ} \mathrm{C}$ warmer. The insulating effect of the apical clefts was also shown by the surrounding air temperature rising rapidly to about $17^{\circ} \mathrm{C}$ in the tropical daylight, while temperatures of the apical areas lagged significantly behind. The apex of $C$. gleichenioides did not go above $10^{\circ} \mathrm{C}$. The dimensions of that plant were similar to those of the $D$. antarctica in the present study, viz trunk height $102 \mathrm{~cm}$ and diameter $26 \mathrm{~cm}$. The corresponding dimensions of the C. atrox var. atrox were 410 and $29 \mathrm{~cm}$. More recently, Taggart \& Wardlaw (2003) reported apical and ambient temperatures of a Cyathea smithii, of New Zealand origin and with about $180 \mathrm{~cm}$ trunk height, growing close to the sea at Linn Botanic Gardens in western Scotland. The apical cleft of this plant experienced several episodes of sub-zero temperatures during the winter of 2001/02. These exposures damaged the fronds at the time but new croziers appeared in the subsequent spring.

We are unaware of published information on apical temperatures of $D$. antarctica under winter conditions, prior to the pilot studies reported here. With only five plants and a single, average, winter which did no damage, it is inappropriate to generalise from our results. They do, however, indicate the feasibility of determining the temperature characteristics of environments where tree ferns thrive, and the extent of thermal insulation provided by the apical cleft. It would now be desirable to make a larger investigation with more tree ferns of diverse sizes and species, in different environments, and over several seasons, so that the effect of exceptional weather, such as severe frosts, could be studied. It would also be worthwhile to measure the atmospheric humidity and light intensity, because of the natural occurrence of $D$. antarctica in humid, shaded forests which horticulture rarely imitates. Moreover, Unwin \& Hunt (1996) demonstrated that photosynthesis in $D$. antarctica is strongly influenced by vapour-pressure deficit. 
In particular, the stomata started to close and photosynthesis diminished even under relatively high humidity conditions. Thus the beneficial 'oceanic' effect on tree-fern growth in western Britain, and possibly in the RBGE courtyard, is likely to be dependent on sufficient atmospheric moisture, as well as on a range of moderate temperatures, together with light of suitable intensity. The long-term objective of such studies would be to gain a better understanding of the ecophysiology of these remarkable plants, both in their native habitats and in horticulture.

\section{ACKNOWLEDGEMENT}

We are very grateful to David Mitchell, Curator of the Indoor Department at RBGE, for his enthusiastic support of this work.

\section{REFERENCES}

EARNSHAW, M.J., GUNN, T.C. \& CROFT, J.R. (1988). Shoot temperature measurements of montane Cyathea (Cyatheaceae, Pteridophyta) species in Papua New Guinea. Fern Gazette: 13: 209-216.

HOSHIZAKI, B.J. \& MORAN, R.C. (2001). Fern Grower's Manual. pp. 604, Portland, Timber Press.

JONES, D.L. (1987). Encyclopaedia of Ferns. pp. 433, Portland, Timber Press.

JONES, D.L. (1998). Dicksoniaceae. pp. 189-191. In Flora of Australia, Volume 48, Ferns, Gymnosperms and Allied Groups. (ed.) McCarthy, P.M. Australia, CSIRO.

PRESTON, C.D., PEARMAN, D.A. \& DINES, T.D. (2002). New Atlas of the British \& Irish Flora. pp. 910. Oxford, Oxford University Press.

RICKARD, M. (1987). Tree-ferns out-of-doors in the British Isles. Pteridologist 1: 182-186.

RICKARD, M. (2000). The Plantfinder's Guide to Garden Ferns. pp. 193. Portland, Timber Press.

TAGGART, J \& WARDLAW, A.C. (2003). Cyathea smithii in Linn Botanic Gardens, Scotland. Pteridologist 4: 48-50.

THE ROYAL HORTICULTURAL SOCIETY (1989). Gardeners' Encyclopaedia of Plants and Flowers. (ed.) Brickell, C. pp. 608. London, Dorling Kindersley.

UNWIN, G.L. \& HUNT, M.A. (1996). Conservation and management of soft tree fern Dicksonia antarctica in relation to commercial forestry and horticulture. pp. 125-137 In Pteridology in Perspective, (eds.) Camus, J., Gibby, M. \& Johns, R.J. London, Royal Botanic Garden, Kew.

WARDLAW, A.C. (2004). Dicksonia antarctica in central London, Pteridologist 4: 83.

WAREHAM, A. \& MAITLAND, S. (2004). East Ruston: a critique. The Garden September 2004: 706-711. 